\title{
INNOVATIVE TRENDS AND OPPORTUNITIES OF EDUCATION IN PUBLIC ADMINISTRATION
}

\author{
[INOVATIVNE TRENDY A MOZNOSTI EDUKACIE VO VEREJNEJ \\ SPRAVE]
}

\author{
Viola Tamasova - Silvia Barnova
}

\section{doi: 10.18355/PG.2016.5.2.378-390}

\begin{abstract}
The theoretical study deals with the issues of education and lifelong learning components in public administration. It points out that the quality of implementation of each profession depends largely on the quality of the concept of lifelong professional development, formulation of its functions, objectives, content types, forms and methods, organization and follow-up legislation to further education and self-education as a trend set by the EU. The system of lifelong education in public administration is carried out on a voluntary basis, to the employees own needs to push the limits of their professional development opportunities further, as required by the needs of the society as a result of economic, cultural, historical and social changes. Education is always linked with the requirements of the employer and the active application in the labor market. In addition to the various types and forms of education, the authors also deal with the implementation of accredited educational projects, career system and growth motivation in education, the problem of formal, non-formal and informal learning and with developing the skills of public employees.
\end{abstract}

\section{Key words}

education in public administration, lifelong education, continuing education, self-instruction, motivation, professional orientation, career development, competencies

\section{Anotácia}

Teoretická štúdia sa venuje otázkam edukácie a komponentom celoživotného vzdelávania vo verejnej správe. Poukazuje na to, že kvalita vykonávania každej profesie závisí vo vel'kej miere od kvality koncepcie celoživotného profesijného rozvoja, formulácie jej funkcií, ciel'ov, obsahu, druhov, foriem a metód, organizácie, legislatívy a nadväznosti na d’alšie vzdelávanie a sebavzdelávanie ako trendu, ktorý vytýčila EÚ. Systém celoživotného vzdelávania vo verejnej správe sa realizuje na základe dobrovol’nosti, vlastnej potreby posunút' hranicu možností svojho profesijného rozvoja d'alej tak, ako to vyžadujú požiadavky spoločnosti v dôsledku ekonomických, kultúrnohistorických a spoločenských zmien. Vzdelávanie je vždy späté s požiadavkami zamestnávatel'a a s aktívnym uplatnením sa na trhu práce. Popri jednotlivých druhoch a formách edukácie sa autorky venujú aj vzdelávaniu realizáciou akreditovaných projektov, kariérnemu systému a rastu, 
motivácii vo vzdelávaní, problémom formálneho, neformálneho a informálneho vzdelávania a rozvíjaniu kompetencií zamestnancov verejnej správy.

\section{Kl’účové slová}

edukácia vo verejnej správe, celoživotné vzdelávanie, d’alšie vzdelávanie, sebavzdelávanie, motivácia, profesijná orientácia, kariérny rast, kompetencie

\section{Úvod}

Kvalita vykonávania profesie závisí vo vel'kej miere od kvality koncepcie celoživotného profesijného rozvoja, formulácie jej funkcií, ciel’ov, obsahu, druhov, foriem a metód, organizácie a nadväznosti na d'alšie vzdelávanie a sebavzdelávanie, ktoré sa stali súčast'ou celoživotného vzdelávania ako trendu v EÚ (Eurydice, 2000). Systém celoživotného vzdelávania sa realizuje na základe dobrovol'nosti, vlastnej potreby posunút' hranicu možností svojho profesijného rozvoja d’alej tak, ako to vyžadujú požiadavky spoločnosti v dôsledku ekonomických, kultúrno-historických a spoločenských zmien. V mnohých literárnych zdrojoch existujú rozličné názory na podstatu a obsah frekventovaného termínu profesijný rozvoj človeka. Našu štúdiu orientujeme preto na vzdelávacie možnosti, inovatívne formy a d'alšie perspektívy vedukácii vo verejnej správe. Vychádzame z myšlienok a požiadaviek celoživotného vzdelávania a sebavzdelávania.

\section{Celoživotné vzdelávanie a jeho formy - spätost' so vzdelávaním vo verejnej správe}

Zákon NR SR 386/1997 Z. z. o d'alšom vzdelávaní v znení neskorších predpisov charakterizuje d'alšie vzdelávanie ako ,súčast' celoživotného vzdelávania, ktoré je popri povinnej školskej dochádzke, stredoškolskom a vysokoškolskom vzdelávaní štvrtým pilierom celoživotného vzdelávania. Ide o vzdelávanie, ktoré umožňuje každému doplnit', rozšírit' a prehíbit' si získané vzdelanie, rekvalifikovat' sa alebo uspokojit' svoje záujmy, alebo ktorým sa pripravuje na získanie stupňa vzdelania v školskom systéme." Druhmi tohto vzdelávania sú:

- vzdelávanie na prípravu alebo získanie stupňa vzdelania,

- odborné vzdelávanie a príprava na rozšírenie, prehíbenie alebo obnovu vedomostí a zručností,

- záujmové a občianske vzdelávanie.

Zákon NR SR 568/2009 Z. z. o celoživotnom vzdelávaní a o zmene a doplnení niektorých zákonov označuje d’alšie vzdelávanie ako „vzdelávanie vo vzdelávacích inštitúciách d’alšieho vzdelávania, ktoré nadväzuje na školské vzdelávanie a umožňuje získat’ čiastočnú kvalifikáciu alebo úplnú kvalifikáciu alebo doplnit', obnovit', rozšírit' alebo prehĺbit' si kvalifikáciu nadobudnutú v školskom vzdelávaní alebo uspokojit' záujmy a získat' spôsobilost' a zapájat' sa do života občianskej spoločnosti.“ Z uvedených údajov je zrejmé, že termín d’alšie vzdelávanie, kam samozrejme zarad'ujeme i termín sebavzdelávanie, nie je presnou definíciou pre vystihnutie podstaty procesov vlastných pre 
profesijný rozvoj človeka po ukončení vysokoškolského vzdelania. Výstižnejším, a preto aj častejšie použivaným termínom, je termín kontinuálne profesijné vzdelávanie (continuing professional education). Tento termín je podl'a Š. Šveca považovaný za charakteristický a adekvátny pre súčasnú teóriu i prax permanentného profesijného rozvoja (Svec, 2002). Svojím obsahom vystihuje realitu profesijného rozvoja viac než doteraz používaný, mnohoznačný termín d'alšie vzdelávanie (further education), ktorý sa používa väčšinou na označenie odborného vzdelávania po ukončení štúdia strednej školy. Podl'a odborníkov, ktorí sa venujú tejto problematike na Slovensku (Kosova, 2005; Kasacova, 2002; Matusova, 2010, 2011, Porubska, 2005; Prusakova, 2000, 2013; Veteska, 2011) je dôležité zdôraznit' potrebu systému celoživotného kontinuálneho vzdelávania a určit' za ciel' zabezpečenie sústavného profesijného rozvoja ako aktívneho štúdia daného odboru, prípadne špecifického zamerania (odborné predmety). Pre obe fázy je základom motivácia. Fáza profesijného štartu - vstup do povolania - je prvou etapou, kde na základe štúdií tejto problematiky je možné definovat' postavenie začínajúceho pracovníka vo verejnej správe ako významný krok na jeho profesionálnej dráhe. Mení sa rola študenta na rolu odborného pracovníka, ktorý preberá existenčnú zodpovednost' za seba samého. Nasledujúce fázy, profesijná adaptácia a profesijný vzostup, sú obdobiami získavania prvých vlastných skúseností a vývojom vlastnej osobnosti. Jeho samotný vývoj prechádza do fáze skúseného experta, ktorý ako uvedomelý praktik vo svojej oblasti s prehl'adom zvláda pracovné návyky, pracovný stres, dokáže riešit' problémové situácie na základe vlastných skúseností, jeho prístup a pracovné návyky majú akýsi pozitívny stupeň rutiny, má dostatočný prehl'ad informácií v oblasti svojho odborného pôsobenia. Fáza profesijnej stabilizácie je obdobím upevňovania svojich profesionálnych zručností, postavenia na pracovisku, prípadne posunu od aktívneho pracovníka k riadiacim pozíciám vo verejnej, či štátnej správe. Uvedenú fázu nie je možné jednoznačne časovo obmedzit' alebo stanovit' pre ňu pevné ohraničenie. Posledná fáza - fáza profesijného vyhasínania - je považovaná za obdobie tzv. preddôchodkového veku, nedá sa však hovorit' o všeobecnom fakte. Nie je to zákonité, že každý človek v tomto období vyhasína. V súčasnej modernej dobe prechod do tejto fázy môžu urýchlit' sociálne alebo ekonomické podnety (strata motivácie, stagnácia, syndróm vyhorenia, pocit nízkeho ohodnotenia práce, potreba zmeny pracovného prostredia, emocionálne vyhorenie) vyskytujúce sa čoraz viac u mladšej generácie (Frankovsky - Lajcin, 2012: 84; Petnuchova, 2013: 51). Pregraduálna príprava vytvára východiskovú etapu a je integrálnou častou vzdelávacieho systému kontinuálneho vzdelávania pri rešpektovaní jednej z dôležitých zásad vo vzdelávaní: iba štúdiom sa nikto nepripravuje na svoju profesiu definitívne. Rešpektovaním tejto zásady vzdelávania treba zdôraznit, že by mali byt' splnené podmienky a požiadavky pre kvalitný profesijný začiatok, teda poskytnutie širokého odborného základu vedomostí a schopností. Sebavzdelávanie je považované za integrálnu súčast' profesijnej dráhy a je dôležitým faktorom zvyšovania kvality učenia, udržiavania a neustáleho zvyšovania spoločenského statusu každej profesie a pozície vo verejnej správe, začleňovania nových poznatkov do aktuálnej praxe. Stupňovanie, rozširovanie,

Slavonic Pedagogical Studies Journal, ISSN 1339-866o, Volume 5 Issue 2, September 2016 
obnovovanie a špecializovanie profesionality je úlohou nadväzujúceho systému d’alšieho vzdelávania, ktoré vyžaduje charakter kontinuality a celoživotného spôsobu vzdelávania. Za ciele systému vzdelávania sú považované rozvíjanie a upevňovanie profesionálnych postojov, ktoré smerujú k stabilizácii každej profesie a $\mathrm{k}$ podpore profesijného rastu.

\section{Význam, funkcie a ciele celoživotného vzdelávania vo verejnej správe}

Štvrtý pilier celoživotnej edukácie umožňuje človeku pripravit' sa na získanie vyššieho stupňa vzdelania, na doplnenie, rozšírenie alebo na prehĺbenie si svojho už nadobudnutého vzdelania, prípadne na zmenu svojej kvalifikácie, a zároveň tak uspokojovat' svoje záujmy a potreby. Ak si chce dospelý človek udržat' určitý životný štandard, úroveň rozumových či nonkognitívnych schopností, musí sa aktívne vzdelávat' (učit') po celý svoj život. Práve tento fakt je považovaný za dôležitý v každej profesii, pretože si to vyžaduje moderná doba a človek musí neustále reflektovat' na zmeny v oblasti vedy, techniky, umenia, ekonomiky, musí reflektovat' na kultúrno-historické a spoločenské zmeny. Len vtedy je schopný spracovávat', prijímat' a sprostredkovat' vždy nové informácie, poznat' objektívnu realitu odrážajúcu skutočnost' i virtuálny svet (Tamasova, Sari, et al., 2012). Na základe predchádzajúcich úvah a $\mathrm{v}$ súlade $\mathrm{s}$ názormi Porubskej (Porubska, 2005: 32 a n), je možné konštatovat', že d'alšie vzdelávanie sa dotýka dvoch základných oblastí:

- súkromnej - človek sa vzdeláva a tým uspokojuje svoje vlastné (sebavzdelávacie) potreby, záujmy, to znamená, že sebavzdelávaním sleduje záujmy svojho individuálneho života a potrieb (napr. rodinného života, odolnost' voči stresu a pod.),

- verejnej - človek sa vzdeláva a tým sleduje záujmy svojho profesijného a spoločenského života (napr. l'ahšie, dostupnejšie riešenie problémov $\mathrm{v}$ pracovnom prostredí).

Ďalšie zvyšovanie, rozširovanie, prehlbovanie, nadobúdanie novej pracovnej kvalifikácie a záujmové vzdelávanie je problematikou, ktorou sa zaoberá relatívne nová disciplína andragogickej vedy, tzv. andragogická pedeutológia. Ide o aplikovanú disciplínu andragogiky, ktorá patrí z hl'adiska metodologického spolu s pedagogikou do širšieho tzv. kmeňového vedného odboru edukológia - výchovoveda. Podla Porubskej a Határa (Porubska - Hatar, 2009) andragogická pedeutológia kladie vel'ký dôraz predovšetkým na (seba)výchovu, (seba)vzdelávanie edukátorov, funkcie edukácie učitel'ov, trénerov, koučov, ciele, metódy, formy, prostriedky výchovy a vzdelávania učitel’ov, vzdelávatel'ov, lektorov, vychovávatel'ov, majstrov odbornej výchovy, výchovných poradcov, atd'. K riešeniu otázok pristupuje $\mathrm{v}$ dvoch smeroch - interdisciplinárne a transdisciplinárne, čím prispieva $\mathrm{k}$ zvyšovaniu kreditu každej profesie a $\mathrm{k}$ jej prestí̌i $\mathrm{v}$ súčasnej znalostnej spoločnosti.

Porubská (Porubska, 2005) vo svojej práci, z ktorej transformujeme niektoré myšlienky pre účely tejto štúdie, venuje pozornost' síce d'alšiemu vzdelávaniu učitelov ako vzdelávaniu dospelých a z pedagogického 
hladiska sa pozerá na význam, funkcie a ciele vzdelávania, ktoré majú individuálny, komunitný a (celo)spoločenský význam, čo však je možné aplikovat' aj na d’alšie vzdelávanie zamestnancov vo verejnej správe. Vzdelávaním a výchovou ako uvádza, sa sledujú ciele: autonómne a heteronómne. Ďalšie vzdelávanie dospelých, aplikovatelné aj na verejnú správu, prispieva k:

1. rozvoju osobnosti dospelého človeka (aspekt individuálnoosobnostný),

2. rozvoju l’udského kapitálu (aspekt spoločensko-profesijný).

Podl'a Porubskej (Porubska, 2005: 100): „nie je správne, ak sú striktne uprednostňované spoločenské záujmy pred záujmami jednotlivca... Treba preto $\mathrm{v}$ istej syntéze zohl'adňovat' tak potreby jednotlivcov, ako aj celej spoločnosti a smerovat' tak k určitému sociálnemu konsenzu.“ A z tohto zorného uhla je potrebné hodnotit' aj edukáciu vo verejnej a štátnej správe a pripravovanú koncepciu a projekty pre inováciu vzdelávania.

\section{Základné funkcie vzdelávania dospelých}

Vo vzt’ahu vzdelávania dospelých k povinnému školskému vzdelávaniu je možné hovorit' o dvoch základných funkciách edukácie vo verejnej správe:

1. náhradná funkcia - podstatou je vytvorenie novej príležitosti nadobudnút' určitý stupeň vzdelania pre dospelého človeka, prípadne uspokojit' svoje vlastné vzdelávacie potreby, ktoré sa stali potrebnými až po vstupe do pracovného pomeru (procesu),

382 2. vlastná (pokračovacia) funkcia - podstatu tvoria také intelektuálne potreby jednotlivcov, ktoré sú spravidla spojené s profesiou, verejným alebo súkromným životom toho-ktorého jedinca.

Pavlov (2002) funkcie vzdelávania rozdeluje na:

1. funkcie základné - primárne, kde patria :

- Kompenzačná - udržiavat' na primeranej úrovni profesijné kompetencie počas celej profesijnej dráhy a kompenzovat' prirodzené procesy zastarávania a rutiny.

- Rozširujúca - postupovat' smerom k odbornej spôsobilosti (napr. d’alší odborný predmet), prípadne získaniu špecializácie na výkon vybraných funkcií a špecifických úloh.

- Adaptačná (uvádzacia) - prispôsobit' sa potrebám a podmienkam trhu práce $\mathrm{v}$ prvých rokoch praxe.

- Inovačná - je ako podmienka permanentného rozvoja a zvyšovania profesionálnej úrovne pracovníka verejnej správy ako systému. Prostredníctvom rozvoja nových profesijných kompetencií môže rezort v pomerne krátkom časovom horizonte ovplyvnit' zameranie a akcieschopnost' vel'kého počtu zamestnancov (napr. na realizácii projektovaných zmien). Ide o potrebné prepojenie teórie a praxe, navrhovaných reforiem a ich aplikovanie $\mathrm{v}$ praxi.

- Motivačná (k sebazdokonal'ovaniu) - prehíbit' a upevnit' sebavzdelávacie návyky a zručnosti, motiváciu pre profesijný a osobnostný rozvoj $\mathrm{v}$ duchu zásady: vhodne, individuálne 
organizované a zmysluplné kontinuálne vzdelávanie predstavuje motiváciu pre celoživotné vzdelávanie.

2. Funkcie sekundárne, kde je vhodné doplnit' v zhode s tematikou štúdie nasledovné:

- $\quad$ hlbšie poznávanie problémov $\mathrm{v}$ štátnej a verejnej správe a $\mathrm{v}$ bežnom občianskom živote,

- lepšie vzájomné poznávanie sa na pracovisku,

- výmena skúseností,

- tvorba príležitostí na návštevu iných miest, pracovísk, čo môže poskytnút:

- možnost' na istý čas prospiet' pri zvýšenej vnímavosti na situáciu,

- možnost' iného pohl'adu vnímania pracovných problémov a postupov,

- odhalenie nástupu stereotypu práce, dogmatizmu, syndrómu vyhorenia.

Finálnym ciel'om kontinuálneho vzdelávania podl'a Zelinu je zlepšenie výchovy dospelých l'udí. Tento ciel' je nemožné realizovat' bez zlepšenia funkcionality osobnosti každého človeka - bez rozvoja tých stránok osobnosti, ktoré sú predpokladom úspešného plnenia ciel'ov jednotlivých pracovných pozícií (Zelina, 1996, In: Pavlov, 2002). Vnútorná motivácia je však štartovacím podnetom pre kontinuálne vzdelávanie. Štúdium a tvorba motivačného systému pre neustály profesijný rozvoj tvoria základ koncepcie d’alšieho vzdelávania. Tento východiskový bod je zároveň novým návrhom pre metodológiu a organizáciu celého systému edukácie vo verejnej a štátnej správe.

Podmienky, $v$ rámci ktorých sa rozvíja sústava kontinuálneho vzdelávania, musia byt' stanovené tak, aby čo najlepšie vyhovovali vzdelávaciemu systému každého pracoviska. Existujú niektoré spoločné znaky a línie vo vývoji, ktoré sú ovplyvnené výraznou globalizáciou a medzinárodnými trendmi edukácie.

Slovenská republika, ako členský štát krajín Európskej únie, má dostatočnú podporu pre zvyšovanie kvality vzdelávania aj podporu pre inovácie vo vzdelávacích programoch. Mnohé projekty vzdelávania vo verejnej aj štátnej sfére sú finančne podporované fondmi EU.

Vzhl’adom na globalizáciu, a na základe medzinárodnej spolupráce $\mathrm{v}$ rámci EU, je možné nadväzne formulovat' aktuálne ciele edukácie vo verejnej správe, ktoré sledujú nasledovné:

- osobnostný a profesijný rast - je potrebné klást' dôraz na aktualizáciu a inováciu vedomostí a zručností,

- zvyšovanie kvality poskytovaného vzdelania, vzdelávacieho systému, vyučovacích metód - podpora medzirezortných vztahov, tímovej práce, medzil'udských vzt’ahov, inovácií a vzdelávania v manažmente pracoviska,

- znalost' sociálneho a životného prostredia - je dôležité dbat' na podporu kontaktov s výrobnou, ekonomickou sférou, skúmanie a 
pochopenie ekonomických a sociálnych faktorov, ktoré ovplyvňujú správanie l'udí.

Činitel'mi realizácie ciel'ov, tzv. determinantami, je súbor faktorov (komponentov), ktoré vzájomným prepojením a spoluprácou môžu, avšak nemusia vytvárat' efektívny systém d'alšieho vzdelávania. Podl'a Tureka (Turek, 2009), stupeň kvality vzdelávania sa odráža v riešení uvedených problémov, v otázkach, ktoré je možné považovat' za základné problémy úrovne vlastného profesijného rozvoja. Dôvody na riešenie otázok je možné posunút' do roviny existencie kvalitného vzdelávania v dnešnej modernej dobe. Faktory, ktoré na uvedené problémy dávajú odpovede sú podl'a V. Tamasovej a Z. Gersicovej (Tamasova - Gersicova, 2014: 18-19) nasledovné:

- koncepcia celoživotného vzdelávania vo verejnej správe, jej legislatívna podpora a inštitucionálne štruktúry,

- financovanie a podmienky účasti na d'alšom vzdelávaní,

- personálne zabezpečenie sústavy d’alšieho vzdelávania,

- obsah, druhy a formy d’alšieho a celoživotného vzdelávania,

- hodnotenie procesov a kvality výsledkov d’alšieho vzdelávania vo verejnej správe a využitia v praxi.

Každý vzdelaný človek si je vedomý toho, že s kompetenciami, vedomost’ami, zručnost'ami a návykmi, ktoré nadobudol počas školských

384 čias, si už v súčasnej dobe nevystačí. Musí sa d’alej vzdelávat', či už v rámci systému formálnej, neformálnej alebo informálnej výchovy, vzdelávania dospelých (v rámci možností organizácie, zariadenia, inštitúcie) alebo vlastným úsilím si zvyšovat’ úroveň vedomostí a informácií v oblasti svojho odboru a kvalifikácie.

\section{Projekty d'alšieho vzdelávania}

Súčasná ekonomická situácia si vyžaduje moderné myšlienky, technický pokrok, vyžaduje napredovanie vinformačno-komunikačných technológiách. Administratíva vyžaduje praktické a rýchle spracovanie údajov. Právne normy v hospodárskej oblasti bolo potrebné upravit' na normy vhodné členskej krajiny Európskej únie. Každý moderne zmýšl'ajúci človek znalostnej spoločnosti (Matusova, 2010) na súčasnom trhu práce si je vedomý toho, že bez nových aktuálnych informácií, nových spôsobov používania IKT, bez intenzívneho čerpania informácií vo vlastnom a príbuznom odbore, v zdokonal'ovaní sa v kl'účových kompetenciách (Tamasova et al., 2013) a prijímaní inovatívnych prístupov vychádzajúcich z nových výskumov o mozgu (Rozvadsky Gugova et al., 2014: 4 a n.) sa mu nepodarí napredovat' vo svojom profesijnom odbornom raste a učení sa. Neustále čerpanie nových informácí́ oceňujú hlavne zamestnávatelia. Prepojenie jednotlivých odborných oblastí vzdelávania s verejnou sférou je preto nevyhnutnou súčast'ou dnešného sveta.

Zamestnanci verejnej správy si môžu vybrat' zo širokej škály aktivít d’alšieho vzdelávania ponúkaných rôznymi inštitúciami. Akreditovanými

Slavonic Pedagogical Studies Journal, ISSN 1339-8660, Volume 5 Issue 2, September 2016 
inštitúciami Ministerstvom školstva, vedy, výskumu a športu SR, poskytujúcimi vzdelávanie zamestnancov a volených predstavitel'ov územnej samosprávy zverejnených Ministerstvom vnútra SR sú Centrum účelových zariadení, stredisko Inštitút pre verejnú správu, Bratislava (Odborná príprava na zabezpečenie preneseného výkonu štátnej správy na úseku bývania), Združenie miest a obcí, región JE Jaslovské Bohunice, Trnava (Pracovno-právne vzt'ahy zamestnancov a volených predstavitel'ov územnej samosprávy), CORA GEO, s.r.o., Martin (Informačný systém samosprávy) a Newport Educational Solutions, s.r.o., Bratislava (Adaptačné vzdelávanie pre novoprijatých zamestnancov obcí a miest, Právne minimum pre zamestnancov obcí, miest a samosprávnych krajov). Okrem uvedených programov, akreditovaný kurz pre zamestnancov verejnej správy poskytuje napr. Akadémia vzdelávania, Ekonomická univerzita $\mathrm{v}$ Bratislave organizuje akreditované špecializované modulárne vzdelávanie pre kontrolórov, kurzy ponúka aj Vysoká škola ekonómie a manažmentu verejnej správy alebo Filozofická fakulta Univerzity Konštantína Filozofa v Nitre a celá škála vzdelávacích aktivít je zverejnená na stránkach Inštitútu pre verejnú správu ${ }^{1}$, ktorý je strediskom Centra účelových zariadení, príspevkovou organizáciou Ministerstva vnútra $\mathrm{SR}^{2}$, d'alej Ministerstva financií $\mathrm{SR}^{3}$ a na Portáli Verejná správa SR, kde si záujemcovia momentálne môžu vybrat' zo školení a videokurzov.

S prípravou potencionálnych zamestnancov vo verejnej správe na výkon povolania je prospešné začat' už na stredných školách rôzneho zamerania. V súčasnosti sa realizuje niekol'ko vzdelávacích programov pre učitel'ov stredných škôl, v rámci ktorých si môžu rozšírit' svoje kompetencie aj v tejto oblasti. V spolupráci s verejnými inštitúciami a organizáciami tak vznikajú hodnotné a prakticky využitel'né vzdelávacie projekty, ktoré sú prístupné celej verejnosti. Uvádzame niektoré z nich:

\section{Projekt „Moderné vzdelávanie pre vedomostnú spoločnost' - Praktická ekonomika"6}

Vzdelávací program o dianí okolo nás v reálnom živote vznikol v spolupráci Metodicko-pedagogických centier a vydavatel'stva TREND Holding. Inovačný vzdelávací program „Praktická ekonomika“ je zameraný na zvýšenie kl'účových kompetencií učitel'ov, umožňuje im v rámci vyučovania prepojit' reálne ekonomické témy prostredníctvom medzipredmetových vzt'ahov do rôznych predmetov iných vzdelávacích oblastí. Vzdelávací program je zameraný na skvalitnenie vyučovania efektívnym využívaním moderných vyučovacích metód (multimédiá, internet a pod.) a aktuálnych informačných zdrojov. Aplikácia teoretických poznatkov do reálneho života sa žiakom predstavuje formou zážitkového učenia, ktoré je zamerané na pochopenie zákonitostí trhu, podstaty výroby a obchodu, zákonitostí podnikatel'ského úspechu v simulovanom

\footnotetext{
${ }^{1}$ www.ivs.sk

2 www.vssr.sk

${ }^{3}$ www.finance.gov.sk
} 
marketingovom prostredí. Projekt je možné realizovat' aj z dôvodu spolufinancovania zo zdrojov EÚ. ${ }^{1}$

\section{Projekt „Myslím ekonomicky“}

Vzdelávací program ekonomického zamerania, ktorého hlavnou zásadou je preferovanie diskusie ako metódy učenia, je zameraný na rozvoj komunikačných zručností a metodickú podporu učitel'ov ekonomických predmetov. Je určený učitel'om so záujmom o inovatívne formy vzdelávania s dôrazom na diskusiu ako spôsobu učenia. Hlavným ciel'om programu je naučit' sa aplikovat' diskusné metódy pri výučbe v rámci rôznych predmetov a pri vedení diskusie podl'a metodiky projektu „Myslím ekonomicky“. Model projektu je založený na princípoch zážitkového učenia. V roku 2011 projekt zaznamenal rapídny nárast požiadaviek, čo bolo vyvolané vlnou pozitívnych referencií $\mathrm{k}$ projektu a záujmu $\mathrm{z}$ radov učitel'ov ekonomických predmetov. ${ }^{2}$

\section{Projekt „Viac ako peniaze“}

Vzdelávací program, ktorý vychádza z požiadavky zvýšenia úrovne finančnej gramotnosti na Slovensku. Garantom realizácie projektu je organizácia Junior Achievement Slovensko (JASR) v spolupráci so Slovenskou bankovou asociáciou. Hlavným ciel'om projektu je zvýšenie odborného a metodického potenciálu

pedagógov, zameranie sa na vzdelávanie v otázkach finančnej gramotnosti tak, aby sa kontinuálne mohli rozvíjat' témy s obsahom Národného štandardu finančnej gramotnosti (NŠFG) u mladých l'udí práve formou netradičných a inovatívnych metód. Projekt má charakter kontinuálneho inovačného vzdelávania, skladá sa z niekol'kých modulov. Po úspešnom absolvovaní programu účastník získa certifikát JASR, ktorý oprávňuje učitel'a realizovat' metódy vzdelávania podl'a programu „Viac ako peniaze“ na škole. ${ }^{3}$

\section{Projekt „Letná škola ekonómie“"}

Projekt vznikol vd'aka spolupráci dvoch vel'kých globálnych spoločností pôsobiacich na Slovensku - Citigroup a General Electrics - so zámerom zlepšenia slovenského ekonomického vzdelávania. Prostredníctvom vlastných nadácií Citigroup Foundation a General Electrics Foundation a spolupráce s nezávislým združením slovenských ekonómov Nadáciou F. A. Hayeka so sídlom v Bratislave, každoročne prispievajú k zorganizovaniu vzdelávacieho programu „Letná škola ekonómie“. Projekt je určený pre približne tridsat' úspešných stredoškolských žiakov a tridsat' stredoškolských učitel'ov ekonomických predmetov a má prispiet' k zvýšeniu kvality vyučovania ekonomických predmetov na stredných školách. Kvalitu programu po jeho skončení hodnotia formou výstupnej

\footnotetext{
${ }^{1}$ www.mpc-edu.sk/projekty

${ }^{2}$ www.myslimeekonomicky.etrend.sk

${ }^{3} \mathrm{http}: / /$ www.viacakopeniaze.sk
} 
reflexie. Zlepšovanie a kvalita tohto projektu je naviazaná na spätnú väzbu od učitel'ov, ktorá je realizovaná šest' mesiacov po ukončení programu formou zhodnotenia aplikácie získaných vedomostí do praxe, či dopadu seminára na kvalitu každodennej práce. Program si neustále zvyšuje svoju úroven.. ${ }^{1}$

\section{Kariérny rast vo verejnej správe}

S celoživotným, kontinuálnym i d’alším vzdelávaním vo verejnej správe súvisí aj kariérny rast. Kariéra je celoživotný proces práce na sebe, je to proces sebatvorby, ktorý umožňuje udržat' sa a byt' konkurencieschopným na trhu práce. Vedlajším produktom tohto procesu je dosiahnutie určitej pracovnej pozície, postupu v zamestnaní, statusu, prestíže.

- Kariérny systém - je súbor pravidiel ustanovených na zaradenie do kariérnych stupňov a kariérnych pozícií.

- Kariérny stupeň - vyjadruje mieru preukázatel'ného osvojenia profesijných kompetencií v rôznych oblastiach výkonu profesie, ktoré človek získava prostredníctvom kontinuálneho vzdelávania a sebavzdelávania. Kariérny stupeň je vyjadrený rámcovým profesijným štandardom. Kariérne stupne odrážajú gradáciu profesijných kompetencií vo verejnej správe počas profesijnej dráhy.

Zamestnanci vo verejnej správe majú minimálne tri kariérne cesty, z ktorých si každý môže na svojej celoživotnej profesijnej dráhe slobodne volit. Šancu kariérneho rozvoja majú všetky kategórie zamestnancov pri akceptovaní odlišnosti ich pregraduálnej prípravy a dosiahnutej kvalifikácie:

- prvá cesta vedie $\mathrm{k}$ celoživotnému udržiavaniu štandardných kompetencií,

- druhá cesta vedie k získaniu kompetencií na úrovni experta, manažéra,

- tretia cesta vedie $\mathrm{k}$ získaniu špecializovaných alebo riadiacich kompetencií - vrcholový, výkonný a riadiaci manažment.

Uskutočňované reformy $\mathrm{v}$ krajinách Európskej únie $\mathrm{v}$ poslednom období menia tradičné prístupy $\mathrm{k}$ jednotlivým profesiám vo verejnej správe, obzvlášt' pod vplyvom reforiem vo Francúzsku.

Kvalita a profesionalizácia je kl’účovým problémom vzdelávacích systémov v globálnom kontexte. Na Slovensku iba pomaly dochádza k principiálnej premene vzdelávania, ktoré nezodpovedá náročným požiadavkám učiacej sa a informačnej spoločnosti deklarovanej Európskou úniou. Neustále sa zvyšujúce požiadavky na pracovný výkon, výzvy, aby boli zamestnanci inovátormi, manažérmi, konzultantmi, prieskumníkmi i tvorivými zamestnancami, si vyžadujú nové profesijné kompetencie. $\mathrm{Na}$ ich dosiahnutie je však potrebné, aby neboli žiadne ohrozujúce faktory, ako je napr:

- $\quad$ starnutie populácie,

- neatraktívnost' niektorých profesií vo verejnej správe,

\footnotetext{
${ }^{1}$ http://www.hayek.sk
} 
- nižšia kvalita personálnej práce riadiacich pracovníkov,

- nedostatočná kvalita pregraduálneho a kontinuálneho vzdelávania vo verejnej správe,

- nedostatočná kvalita personálnej stratégie rezortu,

- nedostatok a nerovnomernost' kvalifikovanosti v jednotlivých regiónoch Slovenska,

- $\quad$ syndróm vyhorenia.

\section{Záver}

Potreba celoživotného vzdelávania vyplýva z práv a povinnosti každého zamestnanca udržiavat' a rozvíjat' si svoje profesijné kompetencie. Umožňuje a motivuje každého účastníka kontinuálneho vzdelávania získavat' nové vedomosti a zručnosti, a tak prehlbovat' profesijný rozvoj a zvyšovat' kariérny rast. Absolvovaním jednotlivých druhov kontinuálneho vzdelávania nadobudne, zdokonalí a rozšíri svoje profesijné kompetencie potrebné pre úspešný výkon odborných a riadiacich činností. Akreditované programy kontinuálneho vzdelávania prispievajú $\mathrm{k}$ stratégii podpory celoživotného vzdelávania zamestnancov prostredníctvom systematického poskytovania informácií a k skvalitneniu ich odbornej a profesijnej úrovne. Absolvovanie týchto programov umožňuje aktualizovat' svoje profesijné kompetencie s dôrazom na využitel'nost' inovácií v oblasti svojej práce.

Vplyv súčasných spoločenských podmienok a faktorov života, technologický rozvoj a informačná explózia podčiarkujú nutnost'vzdelávat' sa počas celého života. Celoživotné vzdelávanie sa stalo súčast'ou moderného života človeka, aj ked' musíme poukázat' na to, že v súčasnosti sú na Slovensku stále určité rezervy, hlavne slabé prepojenie formálneho, neformálneho a informálneho vzdelávania, ktoré je ešte stále len v začiatkoch a zaostáva za mnohými krajinami v rámci EÚ. Zvyšovanie kvalifikácie, špecializácie a potreba d’alšieho vzdelávania však sú v súvislosti so spoločenskými zmenami prioritnou otázkou zámerov sledovaných OECD, napriek určitým rezervám v edukácii na Slovensku.

\section{Bibliographic references}

FRANKOVSKY, M. - LAJCIN, D. 2012. Zvladanie narocnych situacii v manazerskej praci. Praha: RADIX, s.r.o. ISBN 9788087573020.

MATUSOVA, S. 2010. The conditions and assumptions of Slovak sociocultural development model. In Inanička, K. et al. Economic aspect of social justice and human resources, National Centre for European and Global Studies of the SR. Ekonom, pp. 247-273. ISBN 978-80-225-3004-0.

MATUSOVA, S. 2011. Znalostna spolocnost a ludske zdroje. Ruzomberok: VERBUM. ISBN 978-80-848651.

KASACOVA, B. 2002. Ucitel - profesia a priprava. Banska Bystrica: PF UMB. ISBN80-8055-702-0.

Koncepcia celozivotneho vzdelavania v Slovenskej republike. Bratislava: vláda SR. Available online: http://www.minedu.sk/data/USERDATA /DalsieVzdel/VDOC/Koncepcia CZV. zip.

Slavonic Pedagogical Studies Journal, ISSN 1339-866o, Volume 5 Issue 2, September 2016 
KOSOVA, B. 2005. Perspektivy ucitelskeho vzdelavania - vychodiska, paradigmy a spolocenske vyzvy. In Historia, sucasnost a perspektivy ucitelskeho vzdelavania. Banska Bystrica: PF UMB, pp. 24-30. ISBN 8089029-79-5.

Memorandum o CZV: konzultacny proces. 2001. Bratislava: EDIS, EK, Direktorat pre vzdelavanie a kulturu MS SR. ISBN 80-7100-923-7.

PAVLOV, I. 2002. Profesijny rozvoj pedagogickeho zboru skoly. Presov: MPC. ISBN 80-8045-285-7.

PETNUCHOVA, J. 2013. Education for jobs - preparation for the labor market. Acta Technologica Dubnicae, vol. 3, n. 1. pp. 51-59. ISSN 13383965 (Print), ISSN 1339-4363 (Online).

Ponuka vzdelavacich aktivit na september - december 2016. Institut pre verejnu spravu. Available online: http://ivs.sk/vzdelavanie/Ponuka_912a.pdf.

PORUBSKA, G. 2005. Manazment vzdelavania dospelych. Nitra: Pedagogicka fakulta Univerzita Konstantina Filozofa. ISBN 80-969303-0-3. PORUBSKA, G. - HATAR, C. 2009. Kapitoly z andragogiky pre pomahajuce profesie. Nitra: PF Univerzita Konstantina Filozofa. ISBN 9788080945978.

Prehlad vzdelavacich aktivit. Ministerstvo financii SR. Available online: http://www.finance.gov.sk/vzd/Default.aspx?CatID=148.

PRUSAKOVA, V. 2000. Systemovy pristup k dalsiemu vzdelavaniu. Bratislava: Institut pre verejnu spravu. ISBN 80-7261-064-3.

PRUSAKOVA, V. 2013 Key processes in adult education quality. In Tamásová, V. (ed.). Quality in the context of adult education and lifelong education. Dubnica n/V: DTI, pp. 87-95. ISBN 978-80-89400-53-9.

ROZVADSKY GUGOVA, G. et al. 2013. Edukacia akcentujuca docenenie mozgu. Dubnica n/V: DTI. ISBN 978-80-89400-62-1.

SVEC, S. 2002. Zakladne pojmy v pedagogike a andragogike. Bratislava: Iris. ISBN 80-89018-31-9.

TAMASOVA, V. - GERSICOVA, Z. 2014. Socialno-pedagogicky vycvik ako inovativna forma CZV ucitelov SOS. II. Brno: TRIBUN EU, 2014. ISBN 978-80-26-308485.

TAMASOVA, V. - SARI, M. et al. 2012. Quality management system of universities and the quality of education. Baja: EJ College Baja, HU. ISBN 978-963-7290-95-4.

TAMASOVA, V. et al. 2012. Quality and trends in key competence development in andragogical profession. In Tamasova, V. (ed.). Quality in the context of adult education and lifelong education. Dubnica $\mathrm{n} / \mathrm{V}$ : DTI, pp. 21-27. ISBN 978-80-89400-53-9.

TUREK, I. 2009. Kvalita vzdelavania. Bratislava: IURA Edition, s.r.o. ISBN 978-80-78-243-6.

Zoznam akreditovanych vzdelavacich aktivit pre vzdelavanie zamestnancov a volenych predstavitelov uzemnej samospravy. Ministerstvo vnutra SR. Available online: http://www.minv.sk/?zoznam-akreditovanychvzdelavacich-aktivit-pre-vzdelavanie-zamestnancov-a-volenychpredstavitelov-uzemnej-samospravy. 
Zoznam skoleni a videoskoleni. Vzdelavanie. Portal Verejna sprava SR. Available online: http://www.vssr.sk/vyhladavanie/vzdelavanie_.

Doc. PhDr. Viola Tamášová, CSc.

PaedDr. Silvia Barnová, PhD.

Department of School pedagogy and psychology

Katedra školskej pedagogiky a psychológie

Dubnica Institute of Technology in Dubnica nad Vahom

Sládkovičova 533/20, 01841

Dubnica nad Vahom,

Slovakia

tamasova@dti.sk

barnova@dti.sk 